political considerations, but the most interesting of them, that called ESPRIT (where the last two characters stand for information technology) is too young for its benefits to be properly evaluated and costed. Most probably, the Commission is right to think that there are good works it might perform in fields like this, but little would be lost and much might be gained if it set out to foster collaboration in research with much more deliberation.

This is not to say that the Commission must forever drag its feet on research. Curiously, there are many causes that the Commission has itself in the past espoused that could benefit from encouragement - and a little money. Only three weeks ago, the annual general assembly of the European Science Foundation was wringing its hands over the poverty of its plan to build 'networks' of European scientists, ironically stimulated by a study sponsored by the Commission a few years ago. The Commission could also usefully (as it may yet) listen to appeals such as that from the group of European radioastronomers who seek a modest 16 million European Currency Units (roughly $£ 11.4$ million) over five years to establish a centre for the analysis of data gathered during very-long baseline measurements. Such projects are not, of course, alternatives to a programme of applied research, but the fact that they go begging is a sign that the Commission has not yet begun to work effectively on the common ground where success would come most easily and bring the greatest benefits - the effective integration of the technical community without which a common research enterprise will have little purpose.

\section{Licensing the spooks}

\section{The British and US governments are both embar- rassed by the doings of their undercover people.}

WHo would have known, until the British government's attempt to prevent in the Australian courts the publication of a book on its security service that Lord Rothschild, the embryologist and merchant banker, was once a member of that same service, called MI5? This is nevertheless what has emerged from the embarrassing (for the British government) disclosure that Rothschild acted as the intermediary in bringing together Mr Peter Wright, once also a member of MI5 and now living in Australia, and Mr Chapman Pincher, who published a racy account of Wright's tale three years ago. Few will think the worse of Rothschild now; some will now put him in the same daredevil category as Colonel Oliver North, the staff member of the US National Security Agency dismissed last week for alleged gun-running (to Iran) and now described by President Reagan as a national hero.

Popular heroics apart, there is nevertheless a case for believing that spying and spy-catching have got out of hand. Every few months, there seems to be either a serious international incident or a serious domestic crisis in some major capital because of spooky doings (Auckland Harbour, for example). Then there are retaliations (the name of Daniloff refers). The obvious difficulty is that espionage and counter-espionage are unregulated. The obvious solution is that governments employing secret agents should be required to register all salaried agents' identities with an international authority, which would keep the information secret unless asked by the registrant to disclose it (perhaps secretly) to a third party. That way, it would be possible for governments more easily to arrange swaps for agents or even to find out whether people arrested in foreign capitals were in their employ or were merely innocent visitors. By becoming licensed in this way, secret agents would be able to trade selfesteem for the dare-devilry that now sustains them, and would be less inclined to write their memoirs. So long as the international authority were not itself penetrated by agents, the whole business would be made less serious a threat to international good relations; international spy crises might, for example, be defused by mutual consent. Would not such a scheme be worth a trial?

\section{Action against AIDS}

\author{
Governments are moving quickly on publicity \\ about AIDS; should they be doing more?
}

Bотн the British and the French governments have responded well to the latest alarm about the spread of AIDS (acquired immune deficiency syndrome). In both countries, the governments have decided that public education must take precedence in any serious attempt to break the chain of infection by the virus. Plainly that makes sense. Unless people know which features of their personal behaviour expose them to the risk of infection, their self-interest will not coincide with the needs of programmes of public health aimed at averting what could be a cataclysmic infection. One of the several haunting aspects of the problem is that there remain so many features of the natural history of AIDS that are, as yet, unknown. It is not yet known when and for how long, in the course of an infection, a person is capable of infecting others. Whether all those infected, or only a proportion of them, eventually develop AIDS, is another imponderable for the time being. Little is known about the relative risks of transmission in different sexual acts. The case for acting now is that, if all the answers to such questions were gloomy, large proportions of us or our successors would be killed.

It is a pity that young people, at the beginning of their sexual lives, must be the chief targets of public education, but that, too, makes sense; it is not, as usually the case, that young people are especially deserving of consideration (true though that remains) but that they could be especially effective agents for the transmission of a socially damaging and usually venereal disease. To say the least, a young person, during the remainder of his or her lifetime, will on the average have more sexual partners than an older person and will therefore, on the average, be a potential source of infection for a greater number of people. It is also possible that some young people may be unusually promiscuous. To their credit, both governments appear to have faced this part of the problem that confronts them squarely. The British government, with its reputation for being careful about money, has surprised its taxpayers by deciding to spend twice the sum it first thought of ( $£ 20$ rather than $£ 10$ million) on immediate publicity. The French government is wisely emphasizing the need that people should have a ready opportunity of a test for antibodies.

None of this, unfortunately, will throw light on the present incidence of the infection (as distinct from the disease it may ultimately cause). Those who voluntarily seek an antibody test will often be people who suspect they may have run a particular risk. The routine testing of blood offered at transfusion clinics may similarly, as in the United States, be biased by people's recognition that a blood transfusion is the most convenient way of being tested. That is why some means of random testing would, in present circumstances, be beneficial; it would then be possible to tell objectively how great is the present pool of infection, a necessary starting point in estimating more accurately the rate at which infected people progress to overt disease. Schemes for the anonymous testing of pregnant women at antenatal clinics have similarly been advocated as ways of monitoring the spread of AIDS through heterosexual intercourse. The snag is that, in these enlightened days, it is unethical for physicians to test a person's blood without telling him or her what is afoot, whereupon it would be unethical not to disclose the results. The result is that information that would be invaluable for an assessment of the present problem, and which could be collected easily, is not available. The reasons for this self-denial are admirable, but the outcome is ignorance on an important point. If the AIDS problem becomes more serious, societies will find themselves considering a variety of illiberal measures to protect themselves against the pool of those infected; on the face of things, anonymous testing whose results are not disclosed might be a lesser evil that should be more quickly allowed. 